Immunohistochemical Detection of Caspase 8 Expression and Apoptotic index Activities of Tephrosia purpurea Crude Extract in Balb / C Mice Inoculated with HepG2 Cells

Ibrahim Hade Mohammed Israa Tareq Aakool, Anfal Kadhim Abed and Qutaiba Hafedth Nsaif

\title{
Immunohistochemical Detection of Caspase 8 Expression and Apoptotic index Activities of Tephrosia purpurea Crude Extract in Balb / C Mice Inoculated with HepG2 Cells
}

\author{
Ibrahim Hade Mohammed ${ }^{1}$, Israa Tareq Aakool ${ }^{* 1}$, Anfal Kadhim Abed ${ }^{2}$ and \\ Qutaiba Hafedth Nsaif \\ ${ }^{1}$ Department of Biology - College of Science - University of Diyala \\ ${ }^{2}$ Teacher at directorate education of diyala \\ *Israairaqi46@gmail.com
}

Received: 9 May 2018

Accepted: 20 August 2018

\section{$\underline{\text { Abstract }}$}

The aim of this study was to identify immunomodulatory, apoptosis inducing and anticancer activities of aqueous and alcoholic extracts of $T$. purpurea, regarding the size of tumor mass and immunohistochemical detection of caspase 8 expressions and apoptotic index in mice inoculated with HepG2, mouse hepatocellular carcinoma as therapeutic experimental system for human. Forty-eight Balb / C albino mice were injected at legs with $\mathrm{HepG}_{2}$ cells. Tumor size was measured twice a week, note that the measurement time period is one month.

Administration of aqueous extract $(0.3,0.6,1.2) \mathrm{mg} / \mathrm{kg}$ and alcoholic extract of in $(0.25,0.5,1)$ $\mathrm{mg} / \mathrm{kg}$ to HepG2 tumor-bearing mice showed a significant difference $(\mathrm{P} \leq 0.01)$ in tumor size compared with control group. Inhibitory activity of aqueous and alcoholic extracts was dose and duration dependent. The effective doses in reduction of tumor size were $1.2 \mathrm{mg} / \mathrm{kg}$ for aqueous and $1 \mathrm{mg} / \mathrm{kg}$ for alcoholic extract in which HepG2 tumor mass reduced in size for up to $87.9 \%$. HepG2 bearing mice treated with $T$. purpurea aqueous and alcoholic extracts showed significant increase $(\mathrm{P} \leq 0.05)$ in apoptotic index compared with untreated control group.

Extracts of T. purpurea were highly efficient for tumor growth inhibition, causing reduction in the tumor size, and increasing the expression of caspase 8 gene product in tumor tissue. Also, 


\section{DIYYLAL JOURNAL FOR PURE SCIENCES}

Immunohistochemical Detection of Caspase 8 Expression and Apoptotic index Activities of Tephrosia purpurea Crude Extract in Balb / C Mice Inoculated with HepG2 Cells

Ibrahim Hade Mohammed Israa Tareq Aakool, Anfal Kadhim Abed and Qutaiba Hafedth Nsaif

these extracts increased the apoptotic index of H22 tumor cells taken from the legs of transfected animals.

Keywords: Aqueous and alcoholic extract, T. purpurea, HepG2 cells, Caspase 8, Apoptosis Index.

\section{الكثف عن الكيميائية المناعية النسيجية في تعبير الـ (Caspase 8) ونشاط مؤشر الموت الخلوي المبرمج فــي المستخلص الخام من نبتة الحويرة الارجوانية فـي الفئران ذات اللون الامهق الملقحة HepG2 بخلايا}

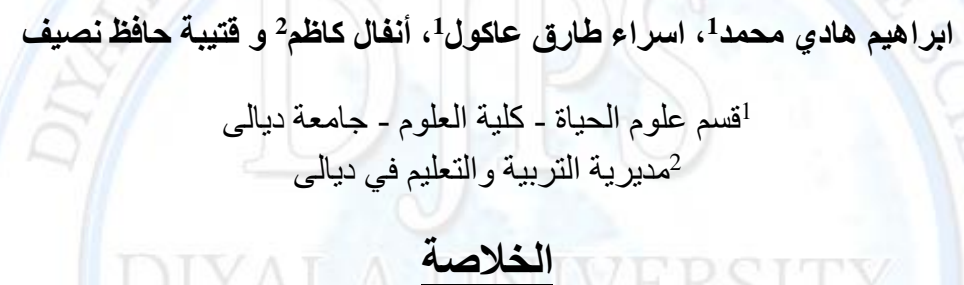

الخلاصة

الهدف من هذه الدراسة هو الكثف عن الكيميائية المناعية النسيجية للموت الخلوي المحفز والمنشط ضد السرطان من المستخلصات المائية والكحولية المستخرجة من عثبة T. purpurea، وكذلك فيما يتعلق بحجم وكتلة الورم و الكثف المناعي لتعبير Caspase 8 والموت الخلوي المبرمج في الفئران الملقحة بخلايا (Hepg2). خلايا الكبد السرطانية في وناي الفئر ان تستخدم كبرنامج علاجي تجريبي بشري. حيث تم حقن أرجل ثمانية واربعون فأر أمهق بخلايا HepG2. ثم قياس حجم الورم مرتين في الأسبوع علما ان الفترة الزمنية للقياس لمدة شهر. كانت الجرعة المستعملة للمستخلص المائي من نبتة T. purpurea (HepG2) . النشاط المثبط للمستخلص المائي و الكحولي يعتمد على الجرعة والمدة الزمنية. أن تاثير الجر عات للحد من حجم الورم كانت. 1.2ملغم/كجم للمستخلص المائي و 1 ملغم / كجم للمستخلص الكحولي، بحيث HepG2 انخفضت كتلة الورم في الحجم حتى

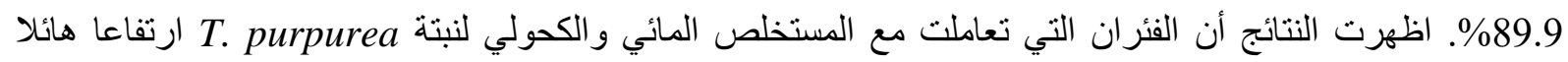

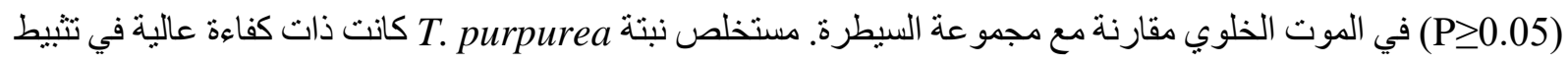
نمو الورم، مما تسبب في الحد من الأورام سريريا وزيادة ابانة Caspase 8 جينيا في نسيج الورم, مسبيا ارتفاع في الموت الخلوي في (H22) خلايا سرطانية التي أخذت من ارجل الحيو انات، مما تسبب في فقدان الأرجل بسبب النخر في العظام. الكلمات المفتاحية: المستخلص المائي و الكحولي، Taspase 8 . purpurea، خلايا CaspG، الموت الخلوي المبرمج. 


\section{Immunohistochemical Detection of Caspase 8 Expression and Apoptotic index Activities of Tephrosia purpurea Crude Extract in Balb / C Mice Inoculated with HepG2 Cells}

\section{Ibrahim Hade Mohammed Israa Tareq Aakool, Anfal Kadhim Abed and Qutaiba Hafedth Nsaif}

\section{$\underline{\text { Introduction }}$}

People are often exposed to free radicals which are generated from normal metabolic processes in the body. Free radicals are not always harmful; however, high level of free groups may disturb the normal cellular mechanism by inducing oxidative damage to DNA, protein and lipids which ultimately result in chromosomal instability and mutation [1]. Antioxidant mechanism delays or prevents free radicals' formation and thereby suppresses the lifethreatening diseases. Besides, it can prevent cancer progression by maintaining normal cell cycle regulation, inhibiting cell proliferation and inducing apoptosis [2].

Numerous plants and their compounds are reported to possess the antioxidant activity which controls many diseases. natural antioxidant compounds have been investigated for various types of treatments including cancer [3]. In this context, we have selected the traditional Indian medicinal plant Tephrosia purpurea for our study. T. purpurea belongs to Fabaceae family, and it is distributed throughout India, popularly known as "Sharpunkha" in Sanskrit and "Wild Indigo" in English [4]. In addition, different parts of this plant are used to treat various like asthma, diarrhea, jaundice, rheumatism and kidney disorders [5].

T. purpurea has also been reported to possess many pharmacological properties such as anticancer, wound healing, hepatoprotective, antiulcer, antimalarial, antimicrobial and antioxidant activities [6]. The CASP8 gene encodes a member of the cysteine -aspartic acid protease (caspase) family. Sequential activation of caspases plays a central role in the execution-phase of cell apoptosis. Caspases exist as inactive proenzymes composed of a prodomain, a large protease subunit and a small protease subunit [7]. Activation of caspases requires proteolytic processing at conserved internal aspartic residues to generate a heterodimeric enzyme consisting of the large and small subunits [8].

Biochemically, caspase- 8 was found to enter the complex of the inhibitor of NF-KB kinase (IKK) with the upstream Bc110-MALT1 (mucosa-associated lymphatic tissue) adapter complex which were crucial for the induction of nuclear translocation of NF- $\kappa \mathrm{B}$ [9]. Moreover, the 


\section{DIYALA JOURNAL FOR PURE SCIENCES}

\section{Immunohistochemical Detection of Caspase 8 Expression and Apoptotic index Activities of Tephrosia purpurea Crude Extract in Balb / C Mice Inoculated with HepG2 Cells}

Ibrahim Hade Mohammed Israa Tareq Aakool, Anfal Kadhim Abed and Qutaiba Hafedth Nsaif

biochemical form of caspase- 8 is differed in the two pathways. In the death pathway, the caspase- 8 zymogen is cleaved into subunits that assemble to form the mature, highly active caspase heterotetramer whereas in the activation pathway, the zymogen appears to remain intact perhaps to limit its proteolytic function but enhance its capability as an adapter protein [10]. It is one of the most recent Iraqi studies that have been interested in this aspect and succeeded in using plant extracts in inhibiting the growth of cancer lines outside the organism and within it the long plant Convolvulues arvensis [11].

The aim of the present study was to explore the anticancer activity of Tephrosia purpurea regarding its Immunomodulatory and apoptosis inducing effects, of the aqueous and alcoholic extracts of this plant, also regarding the size of tumor mass and immunohistochemical detection of caspase 8 expression.

\section{Materials and methods}

\section{Collection and Identification of plant:}

Tephrosia purpurea obtained from groves of Al-Khalis region - Diyala province / Iraq. The classification of plant was achieved at plant research laboratory, by faculty of education college, University of Baghdad-Iraq by professor Athea AL mshhdani. Figure 1 represents the morphology of plant in Iraq collected by our team.

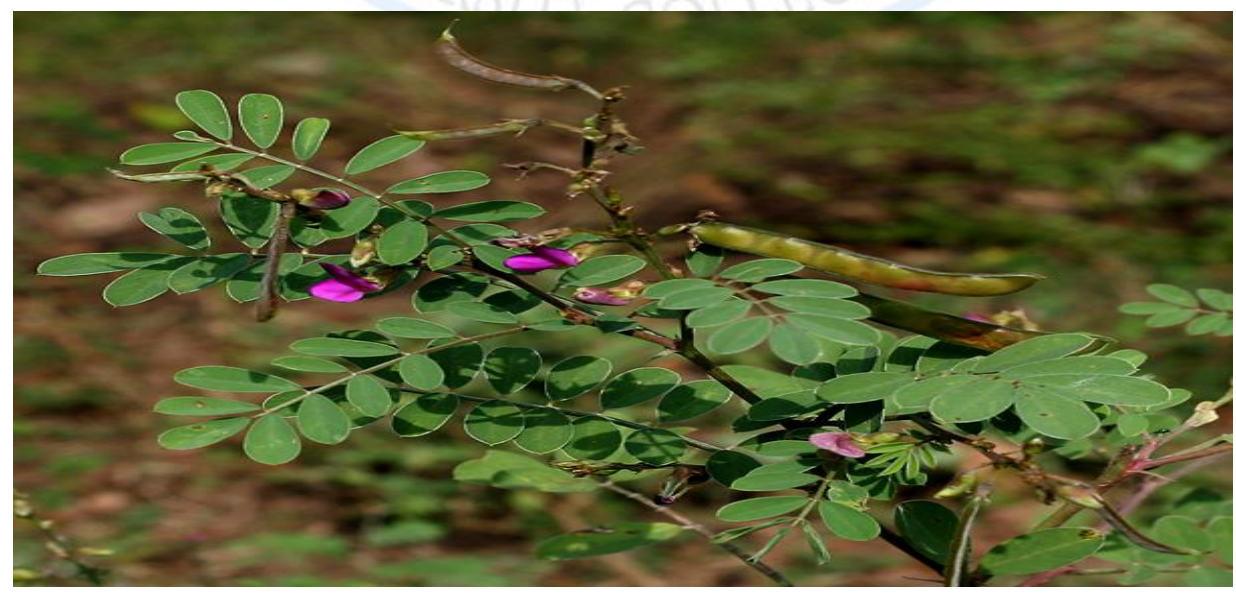

Figure 1: The Tephrosia purpurea 
Immunohistochemical Detection of Caspase 8 Expression and Apoptotic index Activities of Tephrosia purpurea Crude Extract in Balb / C Mice Inoculated with HepG2 Cells

Ibrahim Hade Mohammed Israa Tareq Aakool, Anfal Kadhim Abed and Qutaiba Hafedth Nsaif

\section{Preparation of aqueous and alcohol extract of Tephrosia purpurea:}

For the preparation of the aqueous extract, 50 grams of soft plant was weight and added in to $500 \mathrm{ml}$ of distilled water, and then put 5-10 minutes in a blender for mixing until homogeneity. Extract was put in to a clean sterile bottle and transferred to the Shaker for an hour at $25 \mathrm{C}$, then centrifuged for 10 minutes ( $2000 \mathrm{rpm} / \mathrm{min}$ ), get rid of the sediment and then taking supernatant which then distributed in the clean dry dishes, and left in an incubator to get the dry extract to prepare concentrations used in the study [12].

Tephrosia purpurea crude aqueous extract gave $5 \mathrm{~g}$ out of $75 \mathrm{~g}$ of dry Tephrosia purpurea, i.e. the extraction ratio was $6.66 \%$. The extract was dark brown to black color, thick and little viscous. For preparation of alcoholic extract from raw plant, Soxhlet was used. Twenty (20) g of dry powder was taken and placed in Thimble, in the space provided in the Soxhlet device and hexane was added to remove fat and chlorophyll extraction was conducted for $12 \mathrm{hr}$. at a temperature $\left(40-60{ }^{\circ} \mathrm{C}\right)$. Then after that, the powder was transferred to reflex device with $70 \%$ alcohol methanol for $3 \mathrm{hr}$., The extract was filtered by piece of gauze and filter paper then incubated for $24 \mathrm{hr}$. for evaporation of alcohol.

Alcoholic extract was treated by $\mathrm{HCl} 1 \%$ in a Reflex for half an hour, and then was filtrated. Diethyl ether was added to the filtrate in separating funnel and left for 24 hours. Two layers appeared, the top layer is Diethyl ether layer which had been neglected, and the bottom layer is an aqueous layer that was picked. The PH of aqueous layer was raised for PH 8 by adding ammonia, which is weak base. Then the aqueous extract was incubated to exclude chloroform, the final form of extract was obtained [13]. Crude alcoholic extract gave 5 gm of 50 g, i.e. extraction ratio was $10 \%$ of raw material, the resulting extract have yellowish-brown color, thick and few viscous.

\section{Determination of Acute Toxicity Effect of Tephrosia purpurea:}

To determine any possible toxic effects for aqueous and alcoholic extract of plant, Up-and down method was followed for determination LD50 according to the following equation [14]: $L D_{50}=x F+k d$ 


\section{Immunohistochemical Detection of Caspase 8 Expression and Apoptotic index Activities of Tephrosia purpurea Crude Extract in Balb / C Mice Inoculated with HepG2 Cells}

Ibrahim Hade Mohammed Israa Tareq Aakool, Anfal Kadhim Abed and Qutaiba Hafedth Nsaif

XF: last dose administered

$\mathrm{d}$ : difference between dose levels

k: tabular value calculated from Table (1).

Table 1: the median lethal dose of alcohol and aqueous extract, Type of extract, Difference between dose levels (d) death of the animal or to stay alive after 24 hours the value of $\mathrm{K}$ tabular last dose administered (Xf) midterm lethal dose (LD50).

\begin{tabular}{|c|c|c|c|c|c|}
\hline Type of extract & $\begin{array}{l}\text { Difference } \\
\text { between } \\
\text { dose levels }\end{array}$ & $\begin{array}{l}\text { Death of animal } \\
\text { or to stay alive } \\
\text { after 24 hours }\end{array}$ & $\begin{array}{l}\text { The value of } \\
\text { K tabular }\end{array}$ & $\begin{array}{l}\text { Last dose } \\
\text { administered }\end{array}$ & $\begin{array}{l}\text { midterm lethal } \\
\text { dose }\left(\text { LD }_{50}\right)\end{array}$ \\
\hline Aqueous & 25 & Ooxo & -439 & 100 & $85 \mid \mathrm{kg}$ \\
\hline Alcohol & 50 & oxxx & 1.5 & 200 & $177 \mathrm{mg} \mid \mathrm{kg}$ \\
\hline
\end{tabular}

\section{O: animal survival within 24 hours of injection}

\section{$X$ : the death of animal within 24 hours of injection}

According to acute toxicity study, aqueous extract was administered in the following doses: $0.3 \mathrm{mg} / \mathrm{kg}, 0.6 \mathrm{mg} / \mathrm{kg}, 1.2 \mathrm{mg} / \mathrm{kg}$. Alcoholic extract was administered in the following doses: $0.25 \mathrm{mg} / \mathrm{kg}, 0.5 \mathrm{mg} / \mathrm{kg}, 1 \mathrm{mg} / \mathrm{kg}$.

\section{Experiment animals}

Forty-eight albino Bclb / C mice (weight 18-20 g) were purchased from Drug investigation department -ministry of health (Baghdad, Iraq). The mice were housed under normal condition and with free access to food and water. Animal experiments and animal care carried out according to protocols approved by the institutional committee for animal care and in accordance with the recommendation for the proper use and care of laboratory animals. Mice were divided in to four groups, (6) mice for each one. Three groups received extract and one control group receiving Dimethyl sulphoxide (DMSO).

\section{Cell culture}

Murine Hepatocellular carcinoma cells (HepG2) was received from Tongji Hospital in Tonji University, Joaqon Hughoin (China). The steps for implant tissue carried out under sterile 
Immunohistochemical Detection of Caspase 8 Expression and Apoptotic index Activities of Tephrosia purpurea Crude Extract in Balb / C Mice Inoculated with HepG2 Cells

Ibrahim Hade Mohammed Israa Tareq Aakool, Anfal Kadhim Abed and Qutaiba Hafedth Nsaif

conditions. RPMI (1640) medium used for cultivation of HepG2 hepatocellular carcinoma cell line and development of full growth [15].

\section{Tumor-bearing laboratory animals}

After growing of HepG2, the were harvested from RPMI 1640 Medium and $0.1 \mathrm{ml}$ of cells was injected at the leg of (48) Balb / C albino mice to establish a solid tumor model. [16]. The experiment ending with the death of last mouse from the control group given doses of aqueous and alcoholic extract. tumor size was measured twice a week during the duration of the experiment using special caliber and took the measurement analogy (latitude and longitude), and extracted tumor size [17].

\section{Immunohistochemistry for Detection of Caspase 8}

Immunohistochemistry (IHC) used for evaluation of apoptosis. The procedure of IHC was preformed according to manufacturer's instruction, using polyclonal rabbit anti-mouse caspase $8 \mathrm{IgG}$, ab25901 recognizes the p18 form of Caspase-8 [18]. Secondary antibodies, Biotinylated goat anti-rabbit IgG. Final results visualized by using Immunohistochemistry detection kit, Expose Mouse and Rabbit Specific HRP/DAB Detection IHC kit ab80436 [19].

The primary antibody diluted by the common antibody diluent 1:50. Optimal antibodies concentration may vary depending on specimen and preparation method. Both positive and negative controls were included for each run of caspase 8 detection by IHC. The PBS buffer was used as the negative control, while tonsil tissue was used as positive control [20].

The expression of caspase 8 protein was measured by counting the number of positive cells with brown (DAB) nuclear staining under light microscopy X40. For the evaluation of caspase 8 expression, immunostaining was assessed semi quantitatively using a scoring system for both intensity and extent of staining in 10 microscopic fields which was randomly selected and based on the estimated percentage of caspase 8 positive cells, well where it was staining results were divided into 5 scores , $(0=$ no expression, no positive cells; $1=$ weak expression, less than $40 \%$ 
Immunohistochemical Detection of Caspase 8 Expression and Apoptotic index Activities of Tephrosia purpurea Crude Extract in Balb / C Mice Inoculated with HepG2 Cells

Ibrahim Hade Mohammed Israa Tareq Aakool, Anfal Kadhim Abed and Qutaiba Hafedth Nsaif

positive; 2 = moderate expression, $40-60 \%$ positive cells; 3 = strong expression, more than $60 \%$ but less than $100 \%$ positive cells; $4=$ strong high, $100 \%$ positive cells) [21].

The final results for apoptotic index were expressed as Mean \pm SE and apoptotic index \% was determined according to the following equation [22]

\section{$\frac{\text { Number of divided cells }}{\text { Total cell count }} \times 100$}

\section{Statistical analysis}

Statistical analysis was performed using SPSS version 16 software. One-way Analysis of Variance (ANOVA), used to find out the significance of differences in caspase 8 expression (AI \%) between groups that composed from continuous variables. The level of Significance at $(\mathrm{P}<0.05)$ and $(\mathrm{P}<0.01)$.

\section{$\underline{\text { Result and Discussion }}$}

As shown in figure 2 and table 2, Administration of HepG2 tumor-bearing mice with aqueous extract of T. purpurea at $0.3 \mathrm{mg} / \mathrm{kg}, 0.6 \mathrm{mg} / \mathrm{kg}, 1.2 \mathrm{mg} / \mathrm{kg}$ showed significant differences (P $\leq 0.01$ ) in tumor size compared with control group. Among given doses, $1.2 \mathrm{mg} / \mathrm{kg}$ was effective dose causing reduction in tumor size at last day of experiment (36th), in which tumor size was $960 \mathrm{~mm} 3$ compared with $1564.57 \mathrm{~mm} 3$ for $0.6 \mathrm{mg} / \mathrm{kg}$ and $3559.20 \mathrm{~mm} 3$ for $0.3 \mathrm{mg} /$ $\mathrm{kg}$ while in control group the tumor size was $5747.05 \mathrm{~mm} 3$.

Table 2: Effect of different doses of T. purpurea aqueous extract in Ai\% of HepG2 bearing mice

\begin{tabular}{|c|c|c|}
\hline Dose $\mathrm{mg} \backslash \mathrm{kg}$ & Apoptosis index $\%$ & anova ( $\mathrm{p}$ value $)$ \\
\hline Untreated & 19.32 & \\
\hline 0.3 & 25.34 & \multirow{2}{*}{$\mathrm{P} \leq 0.05$} \\
\hline 0.6 & 26.70 & \\
\hline 1.2 & 27.21 & \\
\hline
\end{tabular}


Immunohistochemical Detection of Caspase 8 Expression and Apoptotic index Activities of Tephrosia purpurea Crude Extract in Balb / C Mice Inoculated with HepG2 Cells

Ibrahim Hade Mohammed Israa Tareq Aakool, Anfal Kadhim Abed and Qutaiba Hafedth Nsaif

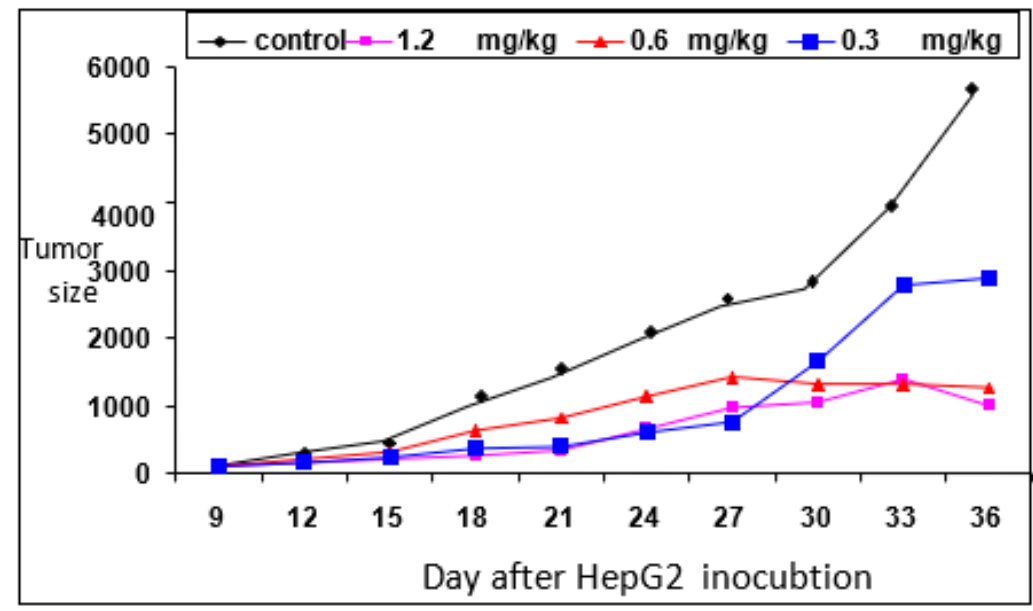

Figure 2: Tumor size follow up in mice inoculated with HepG2 after treatment with Aqueous extract of T. purpurea.

Significant difference with $\mathrm{p}$ value $<0.05$ in tumor size in the leg of inoculated mouse compared with HepG2 bearing mouse in of control group. That loss the legs inoculated with HepG2 cell due to necrosis in the bones.

Administration of HepG2 tumor-bearing mice with methanolic extract of T. purpurea at 0.25 $\mathrm{mg} / \mathrm{kg}, 0.5 \mathrm{mg} / \mathrm{kg}, 1 \mathrm{mg} / \mathrm{kg}$ to showed a significant difference $(\mathrm{P} \leq 0.01)$ in tumor size compared with control group. A significant difference in tumor size throughout the period of experiment was reported. Tumor size was minor increased in treated group compared with control. In last day of experiment $\left(36^{\text {th }}\right)$, the tumor size was $\left(1167.20 \mathrm{~mm}^{3}\right)$ in group treated with $1 \mathrm{mg} / \mathrm{kg}$ compared with $\left(1332.64 \mathrm{~mm}^{3}, 0.5 \mathrm{mg} / \mathrm{kg}\right.$ and $\left.2076.33 \mathrm{~mm}^{3}\right)$ when treated with $(0.25 \mathrm{mg} / \mathrm{kg})$ while in control group the tumor size was $\left(7747.04 \mathrm{~mm}^{3}\right)$ as shown figure 3.

Table 3: the effect of different doses of T. purpurea aqueous extract in Ai\% of HepG2 bearing mice

\begin{tabular}{|c|c|c|}
\hline Dose $\mathrm{mg} \backslash \mathrm{kg}$ & Apoptosis index $\%$ & anova ( $\mathrm{p}$ value $)$ \\
\hline Untreated & 18.30 & \multirow{3}{*}{$\mathrm{P} \leq 0.05$} \\
\hline 0.25 & 24.53 & \\
\hline 0.5 & 25.06 & \\
\hline 1 & 28.16 & \\
\hline
\end{tabular}


Immunohistochemical Detection of Caspase 8 Expression and Apoptotic index Activities of Tephrosia purpurea Crude Extract in Balb / C Mice Inoculated with HepG2 Cells

Ibrahim Hade Mohammed Israa Tareq Aakool, Anfal Kadhim Abed and Qutaiba Hafedth Nsaif

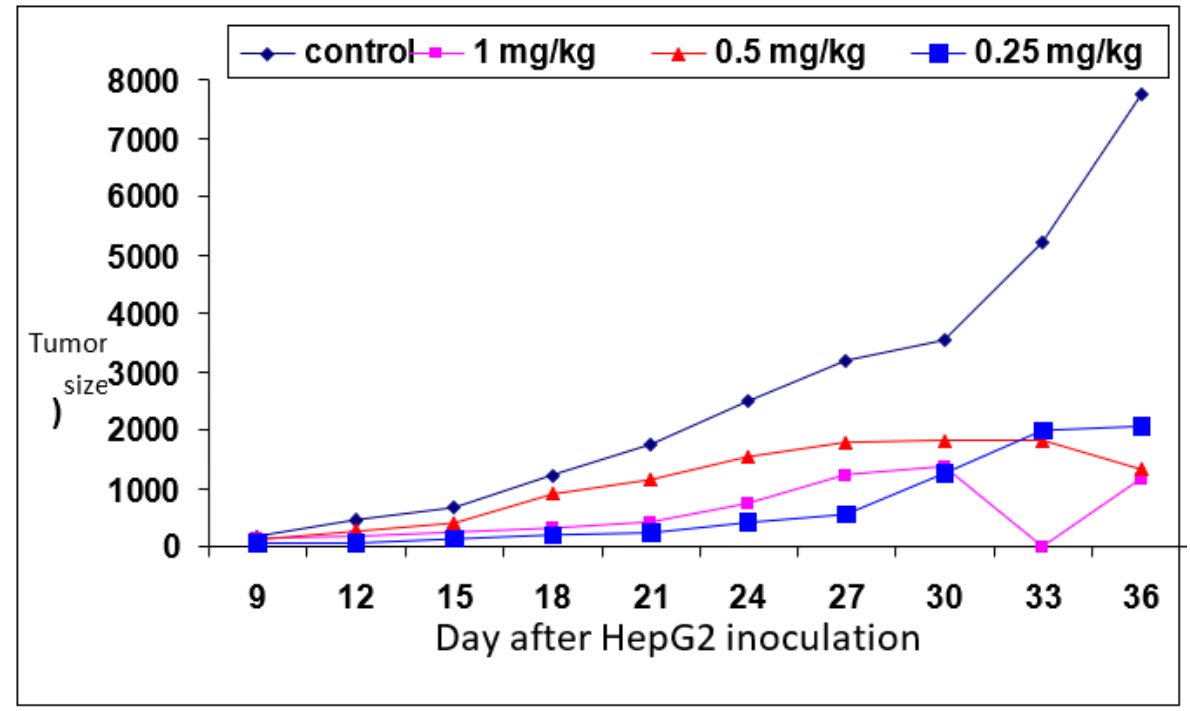

Figure 3 :Tumor size follow up in mice inoculated with HepG2 with Alcoholic extract of T. purpurea.

There is a significant difference in the size of the tumor in the leg of mice with inoculated HepG2 cells where they lead to bone necrosis compared with the mice leg in the control group. Among given doses, $1 \mathrm{mg} / \mathrm{kg}$ was effective dose causing reduction in tumor size in last day (36th), in which tumor size was $1167.28 \mathrm{~mm} 3$ compared with $1332.64 \mathrm{~mm} 3$ for $0.5 \mathrm{mg} / \mathrm{kg}$ and $2076.33 \mathrm{~mm} 3$ for $0.25 \mathrm{mg} / \mathrm{kg}$ while in control group the tumor size was (7747.05) $\mathrm{mm} 3$ as shown figure 3. Inhibitory effect of aqueous and alcoholic extract was dose and duration dependent activity. The extract of $T$. purpurea was effective in reduction of HepG2 tumor size at dose $1.2 \mathrm{mg} / \mathrm{kg}$ for aqueous extract and $1 \mathrm{mg} / \mathrm{kg}$ for alcoholic $87.9 \% \mathrm{mg} / \mathrm{kg}$ as shown in figure $(2 \& 3)$.

As showed in figure (4A) that HepG2 bearing mice treated with $T$. purpurea aqueous extract using three consecutive doses $(0.3,0.6,1.2) \mathrm{mg} / \mathrm{kg}$ showed significant inhibition of tumor size in the leg of mouse compared with HepG2 bearing mouse in control group that loss their HepG2-inoculated legs with Cells. 


\section{DIYALA JOUURNAL FOR PURE SCIENCES}

\section{Immunohistochemical Detection of Caspase 8 Expression and Apoptotic index Activities of Tephrosia purpurea Crude Extract in Balb / C Mice Inoculated with HepG2 Cells}

Ibrahim Hade Mohammed Israa Tareq Aakool, Anfal Kadhim Abed and Qutaiba Hafedth Nsaif

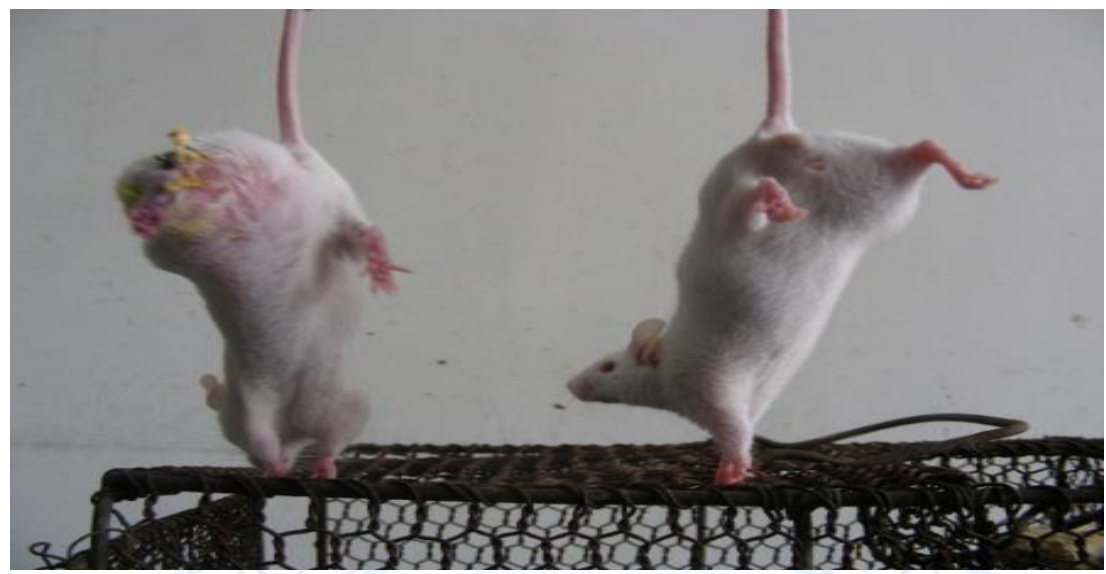

Figure 4A: control group inoculated with HepG2 cancer cell line (left) lost the leg due to bone necrosis and increased tumor size, compared with normal (right)

As showed in table 2 and figure (4B), HepG2 bearing mice treated with $T$. purpurea aqueous extract using three consecutive doses $(0.3,0.6,1.2) \mathrm{mg} / \mathrm{kg}$ in addition to shows significant increase $(\mathrm{P} \leq 0.05)$ in caspase 8 expression and hence in apoptotic index \% $(27.21 \%, 26.70$ $\%, 25.34 \%)$ compared with untreated control group (19.32\%).

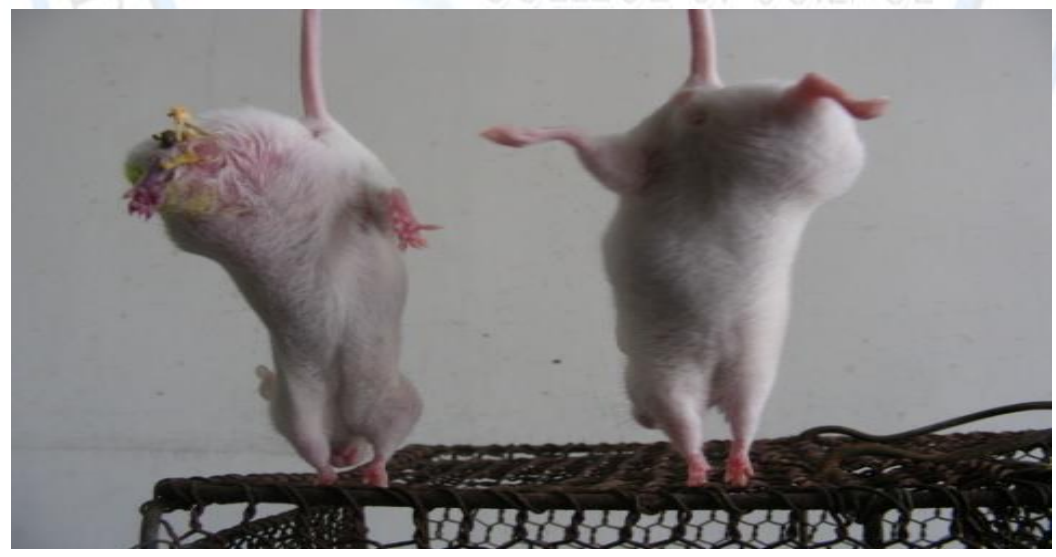

Figure 4B: HepG2 cancer cell line bearing mouse treated with aqueous extract of $T$. purpurea showed inhibition of the tumor growth (right), compared with untreated control inoculated with HepG2 increased tumor size (left) leading to losing of leg due to bone necrosis

Figure 4C shown that HepG2 bearing mice treated with $T$. purpurea alcoholic extract using three consecutive doses $(0.25,0.5,1) \mathrm{mg} / \mathrm{kg}$ shows significant inhibition of tumor in the leg 


\section{Immunohistochemical Detection of Caspase 8 Expression and Apoptotic index Activities of Tephrosia purpurea Crude Extract in Balb / C Mice Inoculated with HepG2 Cells}

\section{Ibrahim Hade Mohammed Israa Tareq Aakool, Anfal Kadhim Abed and Qutaiba Hafedth Nsaif}

of mouse compared with HepG2 bearing mouse in control group that loss the leg inoculated with cells.

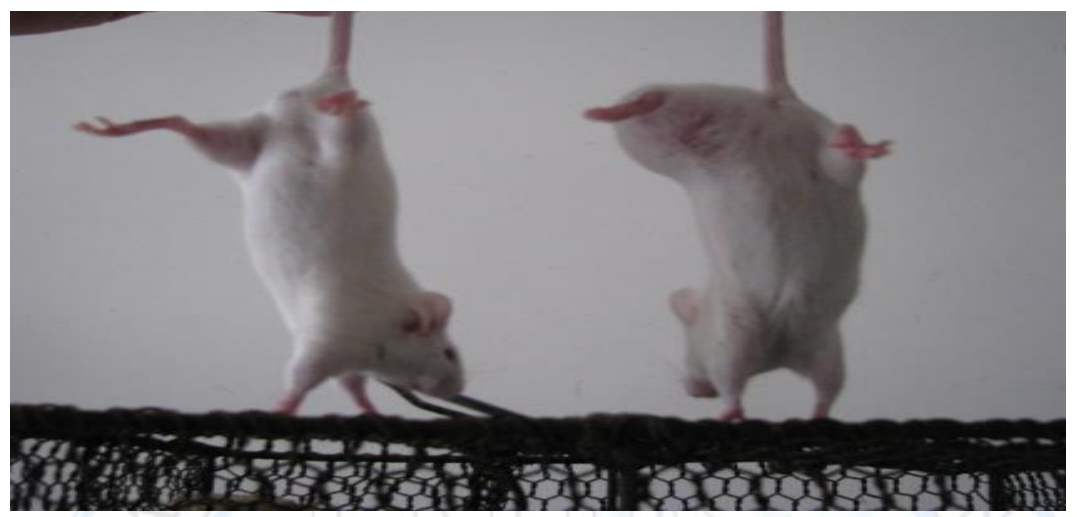

Figure 4C: HepG2 cancer cell line bearing mouse treated with alcoholic extract of $T$. purpurea shows inhibition of the tumor growth (right), compared with untreated control inoculated with HepG2 which increased tumor size leading to losing the leg due to bone necrosis (left)

As shown in table 3 and figure 4B HepG2 bearing mice treated with T. purpurea alcoholic extract using three consecutive doses $(0.25,0.5,1) \mathrm{mg} / \mathrm{kg}$ shows significant increase $(\mathrm{P} \leq 0.05)$ in the caspase 8 expression and apoptotic index $\%(28.16 \%, 25.06,24.53 \%)$ compared with control group (18.30\%).

As shown in table 4, HepG2 bearing mice treated with T. purpurea aqueous extract using three consecutive doses $(0.3,0.6,1.2) \mathrm{mg} / \mathrm{kg}$. It showed an increase in caspase 8 expression in a dose dependent manner. At $0.3 \mathrm{mg} / \mathrm{kg}$, the intensity of expression was strong in (33.33\%) and very strong in $(66.67 \%)$. while at $0.6 \mathrm{mg}$ and $1.2 \mathrm{mg}$ the intensity of expression was strong in $(33.33 \%)$ and very strong in $(100 \%)$. Significant difference $(\mathrm{P} \leq 0.001)$ in caspase 8 expression was reported. In HepG2 bearing mice treated with T. purpurea alcoholic extract using three consecutive doses $(0.25,0.5,1) \mathrm{mg} / \mathrm{kg}$ showed an increase in caspase 8 expression in a dose dependent manner. At $0.25 \mathrm{mg} / \mathrm{kg}$, the intensity of expression was strong in $(33.33 \%)$ and very strong in $(66.67 \%)$. While at $0.5 \mathrm{mg}$, the intensity of expression was strong in $(33.33 \%)$ and very strong in $(100 \%)$. At $1 \mathrm{mg}$, the intensity of expression was strong in (16.67\%). 


\section{DIYALA JOURNAL FOR PURE SCIENCES}

\section{Immunohistochemical Detection of Caspase 8 Expression and Apoptotic index Activities of Tephrosia purpurea Crude Extract in Balb / C Mice Inoculated with HepG2 Cells}

\section{Ibrahim Hade Mohammed Israa Tareq Aakool, Anfal Kadhim Abed and Qutaiba Hafedth Nsaif}

Table 4: Effect of different doses of T. purpurea extraction on caspase 8 expression of HepG2 bearing mice

\begin{tabular}{|c|c|c|c|c|c|c|c|}
\hline \multirow[t]{2}{*}{ Score } & \multirow[t]{2}{*}{ Control group } & \multicolumn{3}{|c|}{$\begin{array}{c}\text { HepG2 bearing mice treated with } \\
\text { aqueous extracts }\end{array}$} & \multicolumn{3}{|c|}{$\begin{array}{c}\text { HepG2 bearing mice treated with } \\
\text { aqueous extracts }\end{array}$} \\
\hline & & $0.3 \mathrm{mg}$ & $0.6 \mathrm{mg}$ & $1.2 \mathrm{mg}$ & $0.25 \mathrm{mg}$ & $0.5 \mathrm{mg}$ & $1 \mathrm{mg}$ \\
\hline 0 & $1(16.67 \%)$ & $0(\%)$ & $0(\%)$ & $0(\%)$ & $0(\%)$ & $0(\%)$ & $0(\%)$ \\
\hline 1 & $3(50 \%)$ & $0(\%)$ & $0(\%)$ & $0(\%)$ & $0(\%)$ & $0(\%)$ & $0(\%)$ \\
\hline 2 & $2(33.33 \%$ & $0(\%)$ & $0(\%)$ & $0(\%)$ & $0(\%)$ & $0(\%)$ & $0(\%)$ \\
\hline 3 & $0(0 \%)$ & $2(33.33 \%)$ & $0(\%)$ & $0(\%)$ & $2(33.33 \%)$ & $4(66.67 \%)$ & $1(16.67 \%)$ \\
\hline 4 & $0(0 \%)$ & $4(6.67 \%)$ & $6(100 \%$ & $6(100 \%$ & $4(66.67 \%)$ & $2(33.33 \%)$ & $5(83.33 \%)$ \\
\hline $\begin{array}{l}\text { Total no. } \\
(\%) \text { of } \\
\text { animals } \mathrm{p} \\
\text { value }\end{array}$ & $6(100 \%)$ & $6(100 \%)$ & $6(100 \%$ & $6(100 \%$ & $6(100 \%)$ & $6(100 \%)$ & $6(100 \%)$ \\
\hline
\end{tabular}

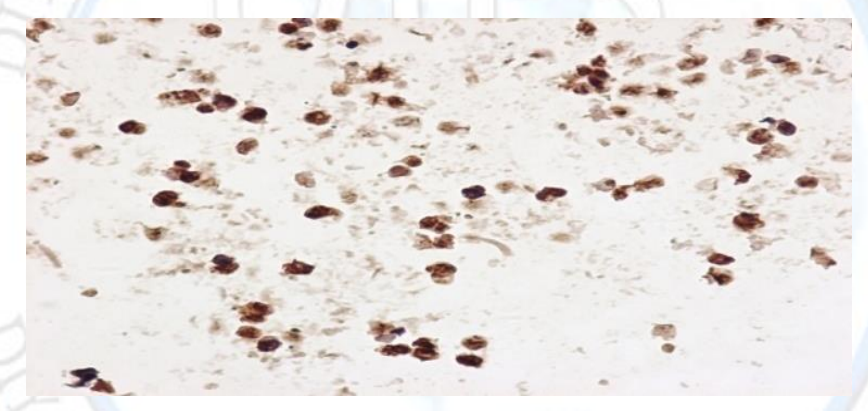

Figure 5A: Tissue sections from leg of HepG2 bearing mouse treated with crude aqueous extract of $T$. purpurea. Up to $40 \%$ Cells with positive staining of caspase 8 expression stained with DAB chromogen (dark brown) counterstained with Mayer's hematoxylin. (400X)

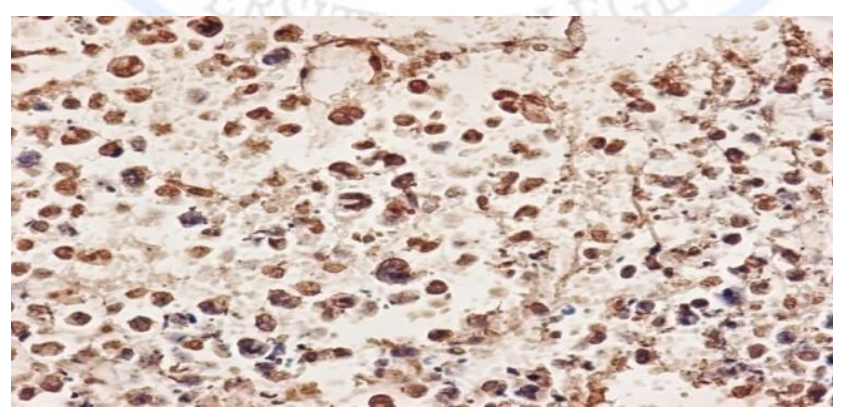

Figure 5B: Tissue sections from leg of HepG2 bearing mouse treated with crude alcoholic extract of plant. Up to $100 \%$ of Cells with positive caspase 8 expression stained with DAB chromogen (dark brown) counterstained with Mayer's hematoxylin. (400X) 


\section{Immunohistochemical Detection of Caspase 8 Expression and Apoptotic index Activities of Tephrosia purpurea Crude Extract in Balb / C Mice Inoculated with HepG2 Cells}

\section{Ibrahim Hade Mohammed Israa Tareq Aakool, Anfal Kadhim Abed and Qutaiba Hafedth Nsaif}

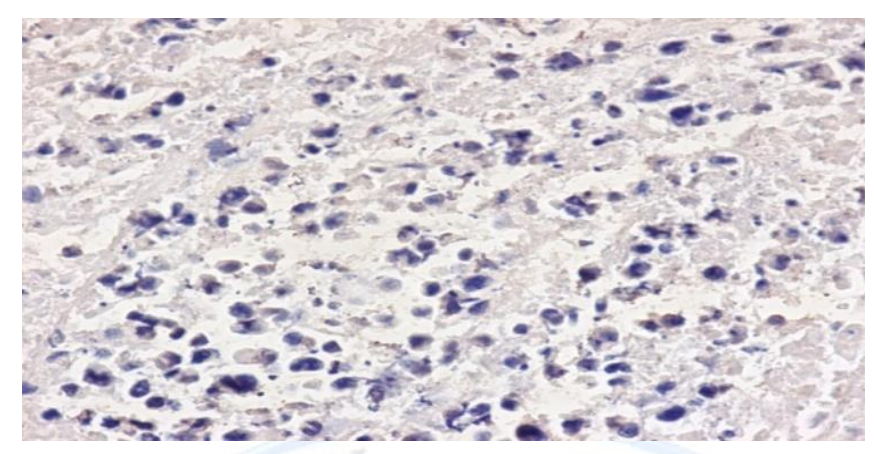

Figure 5 C: Untreated HepG2 hepatocellular carcinoma (control group)

Figure 5: Immunohistochemical staining tissue sections from leg of HepG2 murine hepatocellular carcinoma bearing mouse showed cellular expression of caspase 8:

In the current study, administration of aqueous and alcoholic extracts of T. purpurea at $0.3 \mathrm{mg}$ / kg, $0.6 \mathrm{mg} / \mathrm{kg}, 1.2 \mathrm{mg} / \mathrm{kg}$ and at $0.25 \mathrm{mg} / \mathrm{kg}, 0.5 \mathrm{mg} / \mathrm{kg}, 1 \mathrm{mg} / \mathrm{kg}$ respectively to HepG2 tumor-bearing mice showed significant differences $(\mathrm{P} \leq 0.01)$ in tumor size compared with the control group.

Among given doses, $1 \mathrm{mg} / \mathrm{kg}$ of alcoholic extract was the effective the dose causing reduction in tumor size in last day $\left(36^{\text {th }}\right)$, in which tumor size was $1167.28 \mathrm{~mm}^{3}$ compared with $(7747.05$ $\mathrm{mm}^{3}$ ) of control group. This come in line with others who stated that the intake of mushrooms has high anti-tumor activity and a preventive effect in tumor metastasis [23].

It contains different bioactive polyphenolic compounds. These compounds act as effective antioxidants based on their ability to scavenge free radicals and act as reducing agents. It was supposed that the puffball antioxidant capacity is attributed to the presence of various chemicals such as ascorbic acid, carotenoids, esterified phenolics, free- non-flavonoid phenolics and flavonoids [24].

Also attributed to ergosterol such as ergosteryl ester, gallic, homogentisic, protocatechuic, phydroxybenzoic, p-coumaric acids, alkaloids, steroids, terpenoids [25] and selenium which protect cells from damage that might lead to chronic diseases and help to strengthen the immune system, as well [26]. 


\section{Immunohistochemical Detection of Caspase 8 Expression and Apoptotic index Activities of Tephrosia purpurea Crude Extract in Balb / C Mice Inoculated with HepG2 Cells}

\section{Ibrahim Hade Mohammed Israa Tareq Aakool, Anfal Kadhim Abed and Qutaiba Hafedth Nsaif}

The aqueous extract of $T$. purpurea was effective in reduction of HepG2 tumor size at dose 1.2 $\mathrm{mg} / \mathrm{kg}$ and $1 \mathrm{mg} / \mathrm{kg}$ for alcoholic in which HepG2 tumor mass was reduced in size for up to $87.9 \% \mathrm{mg} / \mathrm{kg}$. The reduction in tumor size prove the presence of restriction in the tumor growth, angiogenesis.

Apoptosis induction as well as increase in the activity of Immune system explains the against cancerous cells. This come in line with the fact that $\beta$-D-glucans which is one of important constituent of $T$. purpurea have the ability to inhibit tumor growth through inhibition of DNA polymerase and have the ability to modify on co-protein gene expression [27]. A protein bound polysaccharide stimulates the functional maturation of macrophages and have an ability to scavenge active oxygen species which is widely prescribed for cancers of digestive organs like stomach, esophagus colon etc. [28].

Hep G2 bearing mice treated with $T$. purpurea aqueous extract using three consecutive doses $(0.3,0.6,1.2) \mathrm{mg} / \mathrm{kg}$ showed significant increase in caspase 8 expression and hence in apoptotic index \% $(27.21 \%, 26.70$ ، \% 25.34\%) compared with untreated control group (19.32\%). H22 bearing mice treated with $T$. purpurea alcoholic extract using three consecutive doses $(0.25$, $0.5,1) \mathrm{mg} / \mathrm{kg}$ showed significant increase in the caspase 8 expression and apoptotic index $\%$ $(28.16 \%, 25.06,24.53 \%)$ compared with control group $(18.30 \%)$.

The cytotoxic effects started by induction of apoptotic process. Apoptosis can be induced via 2 different pathways. The extrinsic pathway is triggered by ligation of death receptors such as CD 95 and recruition of caspase-8 to the death-inducing signaling complex [29]. The intrinsic pathway is initiated by the release of cytochrome $c$ from the mitochondria, which interacts with apoptosis protease activating factor-1 (APAF-1), caspase-9 and deoxyadenosine triphosphate to form the apoptosome complex. Links between the death receptor and the mitochondrial pathway exist at different levels [30].

One of possible pathways in HepG 2 tumor inhibition is the activation of tumor necrosis factorrelated apoptosis-inducing ligand (TRAIL) which is a cytokine that is produced and secreted by most normal tissue cells. TRAIL plays a critical role in the NK cell-mediated and IFN- $\gamma-$ dependent suppression of subcutaneous growth of TRAIL-sensitive tumors [31]. 


\section{Immunohistochemical Detection of Caspase 8 Expression and Apoptotic index Activities of Tephrosia purpurea Crude Extract in Balb / C Mice Inoculated with HepG2 Cells}

\section{Ibrahim Hade Mohammed Israa Tareq Aakool, Anfal Kadhim Abed and Qutaiba Hafedth Nsaif}

There are several reports on $T$. purpurea containing more than one polysaccharide with antitumor activi-ty. The responses to different polysaccharides are mediated by different cell surface receptors, which may be present only on specific subsets of cells and may trigger distinct downstream responses. A combination of such responses involving different cell subsets could conceivably provide greater tumor inhibition than could be induced by a single polysaccharide [32]. These compounds act as effective antioxidants based on their ability to scavenge free radicals and act as reducing agents. Different types of bioactive organic compounds showing antioxidant activities were isolated from Tuber sp. These include, ergosterol such as ergosteryl ester, wide range of phenolic acids such as gallic, homogentisic, protocatechuic, p-hydroxybenzoic, and o- and p-coumaric acids, and other phenolic derivatives such as 3,4-dihydroxybenzaldehyde. Mushrooms are the leading source of the essential antioxidant selenium, which protect cells from damage that might lead to chronic diseases and help to strengthen the immune system, as well [33].

Gluco-oligosacharide present in T. purpurea have anticancer therapeutic effects due to its activation for T lymphocytes and NK cells as well as phagocytic cells. It also underwent an increase in production of Tumor necrosis factor $(\mathrm{TNF}-\alpha)$ as well as increase macrophages cytotoxicity against tumor cells via perforin - granzyme system [34].

Increase in expression of caspase 8 leads to increase $\mathrm{Ai} \%$ and reduction in tumor size in dose and duration dependent manner this primarily due to the effect of antioxidant and inhibitory compounds found in T. purpurea which triggered the apoptotic signals in tumor cells after binding with tumor cells such as Lectins, Ergothioneine, Gluco - oligosacharide which are main chemicals appeared after conducting chemical analysis of the components of the head fruiting of $T$. purpurea by our team. Some of these compounds have hematopoietic and immunomodulatory activities which bringing the importance of its use in vivo, particularly in experimental animals as the use of these component led to inhibition of cancerous cells. Gallic acid which is one of components of $T$. purpurea have cytoprotective action and have the ability to maintain the cells from damage [35]. Several major sub-stances with immunomodulatory and/or antitumor activity have been isolated from $\mathrm{C}$ craniiformis. The-se include mainly 


\section{Immunohistochemical Detection of Caspase 8 Expression and Apoptotic index Activities of Tephrosia purpurea Crude Extract in Balb / C Mice Inoculated with HepG2 Cells}

\section{Ibrahim Hade Mohammed Israa Tareq Aakool, Anfal Kadhim Abed and Qutaiba Hafedth Nsaif}

polysaccharides (in particular $\beta$-D-glucans), polysaccharopeptides (PSP), polysaccha-ride proteins, and proteins. Furthermore, other bioactive substances, including triterpenes, lipids, and phenols, have been identified and characterized in mushrooms with proven medicinal properties.

As in another studies on, $T$. purpurea the possible anti-tumor activity of $T$. purpurea may achieved due to various mechanisms mainly by Inhibition of DNA of tumour cells, Enhancement of cytokine production, Antitumour activity in wide range of animal systems, Tumour cell killing effect, Inhibition of carcinogenesis, Antioxidant effects, Induction of apoptosis and antiproliferative effect; anti-invasion effects and anti-angiogenesis effects; Tumouricidal and cytotoxici-ty effects; antimetastic activity; Immunoprotective effects during radiation and chemotherapy [36].

Various experimental evidences demonstrated that the anti-tumor action of plant polysaccharides is due to the enhancement and potentiation of cell-mediated immune system through the regulation of immunomodulatory cytokines and activation of the complement system and Natural Killer Cells (NK cells) [37].

The obvious effect of $T$. purpurea is to stop the process of $T$ lymphocytes apoptosis, a cell which responsible for fighting against viral infections who can dodge the immune system and also urged the liver cells to kill lymphocytes $\mathrm{T}$ effective. It was noted that the liver cells infected with $\mathrm{HCV}$ can urge or speed up the process of getting rid of activated $\mathrm{T}$ lymphocytes via apoptosis. Murine hepato - cytes expressing a transgene encoding the HCV structural proteins core, envelope 1 (E1) and envelope 2 (E2) enhance apoptosis of activated T cells. Unlike normal liver, which appears to selectively remove on-ly activated CD8+ T cells, enhanced apoptosis determines for both CD4+ and CD8+ T cells via Fas-FasL dependent pathway. [38].

\section{Conclusions}

Extracts of $T$. purpurea were highly efficient in HepG2 tumor growth inhibition, causing reduction in the tumor size clinically and increase the expression of caspase 8 gene product in tumor tissue. This effect causing increase in apoptotic index of HepG2 tumor cells taken from legs of inoculated animals, causing protection of HepG2 inoculated legs from losing compared 


\section{Immunohistochemical Detection of Caspase 8 Expression and Apoptotic index Activities of Tephrosia purpurea Crude Extract in Balb / C Mice Inoculated with HepG2 Cells}

\section{Ibrahim Hade Mohammed Israa Tareq Aakool, Anfal Kadhim Abed and Qutaiba Hafedth Nsaif}

with untreated control group which loss their legs due to necrosis and destruction in the bones. Antitumor activity of $T$. purpurea aqueous and alcoholic extract was dose and duration dependent. These finding indicate the significance of $T$. purpurea extracts as a novel antitumor agent for hepatocellular carcinoma, with its proved apoptosis induction through caspase 8 activation pathway.

\section{$\underline{\text { References }}$}

1. R. A. Jacob, B. J. Burri, Am J Clin Nutr., 63(6), 985S-990 S (1996).

2. P. T. Schumacker, Cancer Cell., 27(2),156-157(2015).

3. Z. luraekova, Physiol Res., 59, 459-469(2010).

4. F. Bonomini, L.F. Rodella, R. Rezzani, Aging Dis., 6(2), 109-120(2015)

5. J. M. Mates, Toxicology, 153,83-104(2000).

6. M. Valko, D. Leibfritz, J. Moncol, M.T.D. Cronin, M. Mazur, J.Telser , Int J Biochem Cell Biol., 39(1), $44-84$ (2007).

7. K. B. Pandey, S. I. Rizvi, Oxid Med Cell Longev., 2(5),270 - 278(2009).

8. O. Firuzi, R. Miri, M. Tavakkoli, L. Saso, Curr Med Chem. 18(25),3871-3888(2011).

9. R.N. Chopra, S.L. Nayar, I.C. Chopra, Glossary of Indian medicinal plants. New Delhi: Council of scientific and industrial research, 1956, p. 234.

10. K.R. Kirtikar, B. D. Basu, Indian medicinal plants. $2^{\text {nd }}$ ed. (Allahabad, Lalit Mohan Basu, 1956), pp. 126.

11. I. H. Al-Rubaie, Effect of water extract and long-term alkaloids Convolvulus arvensis L. in inhibition of cancer cells inside and outside the body, PhD thesis, University of Baghdad, Baghdad, Iraq, (2009)

12. V. Gulecha, T. Sivakuma, Asian Pac J Trop Med., 4, 526 - 529(2011)

13. S. Shenoy, K. Shwetha, K. Prabhu, R. Maradi, K. Bairy, T. Shanbhag, Asian Pac J Trop Med., 3(3),193 - 195(2010)

14. P. Pavana, S. Sethupathy, K. Santha, S. Manoharan, Afr J Tradit CAM., 6, 78 - 86(2009)

15. S. Lodhi, R.S. Pawar, A.P. Jain, A.K. Singhai, J Ethnopharmacol., 108,204 - 210(2006)

16. A. Khatri, A. Garg, S. S. Agrawal, J Ethnopharmacol., 122,1 - 5(2009)

17. A. Chinniah, S. Mohapatra, S. Goswami, A. Mahapatra, S.K. Kar, U.V. Mallavadhani, J Ethnopharmacol., 124,642 - 645(2009) 
Immunohistochemical Detection of Caspase 8 Expression and Apoptotic index Activities of Tephrosia purpurea Crude Extract in Balb / C Mice Inoculated with HepG2 Cells

Ibrahim Hade Mohammed Israa Tareq Aakool, Anfal Kadhim Abed and Qutaiba Hafedth Nsaif

18. A. Patel, N.M. Patel, Pharmacogn Res., 2(3),152 - 158(2010)

19. M. A. A. Rahman, S. Moon, Bull-Korean Chem Soc., 28,827 - 831(2007)

20. Z. D. He, K. M. Lau, H. X. Xu, P. C. Li, P. H. But, J Ethnopharmacol, 71(3), 483 - 486(2000)

21. T. Mosmann, J Immunol Methods, 65(1-2), 55 - 63(1983)

22. Y. Zou, Y. Lu, D. Wei, J Agric Food Chem, 52(16), 5032 - 5039(2004)

23. S. H. Nile, C. N. Khobragade, IJNPR, 2(1), $52-58(2011)$

24. G. P. Choudhary, Anc Sci Life, 27(1), 26-30(2007)

25. E. Fibach, E. Rachmilewitz, Curr Mol Med., 8(7), 609-619(2008)

26. S. Audomkasok, W. Singpha, S. Chachiyo, V. Somsa, J of Pathogen, 1 - 30(2014).

27. M. Ramchoun, K. Sellam, H. Harnafi, C. Alem, M. Benlyas, F. Khallouki, Asian Pac J Trop Biomed, 5(2), 93 - 100(2015)

28. T. Hussain, H. H. Siddiqui, S. Fareed, M. Vijayakumar, C.V. Rao, TPE. J Pharmacol, 64(8), $1195-1205(2012)$

29. S. Lee, Y. Lee, Y. J. Choi, K.S. Han, H.W. Chung, Journal of ethnopharmacology, 152(2), 372376(2014)

30. G. S. Salvesen, C. M. Walsh, Seminars in immunology: 2014. Elsevier: 246-252.

31. D. R. McIlwain, T. Berger, T. W. Mak, Cold Spring Harbor perspectives in biology, 5(4), a008656(2013)

32. C. Y. Wang, M.W. Mayo, R.G. Korneluk, D. V. Goeddel, A.S. Baldwin, Science, 281(5383), 1680 - 1683(1998)

33. H. J. Z. L Chun, M. Ahmad, J. Wang, C. K. Speirs, R. M. Siegel, J. K. Dale, J. Puck, J. Davis, C. G. Hall, S. Skoda-Smith, T. P. Atkinson, S. E. Straus, M. J. Lenardo, Nature, 419 (6905), 395 399(2002)

34. J. Sträter, I. Herter, G. Merkel, U. Hinz, J. Weitz, P. Möller, International Journal of Cancer, 127(4), 873 - 880(2010)

35. M. B. T. Teh, L. S. Kong, G. Y. Bee, Cancer 95(3),499-505(2002)

36. J. Wu, F. Zhu, Nature, 413,36-37(2001)

37. K. Takeda, M. J. Smyth, E. Cretney, Y. Hayakawa, N. Yamaguchi, H. Yagita, K. Okumura, Cellular immunology, 214(2), 194 - 200(2001)

38. D. Finlay, K. Vuori, Cancer research, 167(24), 11704 - 11711(2007) 